\title{
Culture of Individually Required Number of 2-Pronuclei-Stage Oocytes - Patient Participation in Decision-Making is in Accordance with the Aim of Avoiding Surplus Embryo Freezing
}

Kultur einer individuell bestimmten Anzahl von 2-PN-Stadien unter Berücksichtigung der individuellen
Patientinnenwünsche vor dem Hintergrund des Deutschen Embryonenschutzgesetzes

Authors

Affiliations
S. Cupisti ${ }^{1}$, A. Müller ${ }^{2}$, T. Hildebrandt ${ }^{1}$, J. Hackl ${ }^{1}$, M. W. Beckmann ${ }^{1}$, R. Dittrich ${ }^{1}$

1 Gynaecology and Obstetrics, University Hospital, Erlangen

${ }^{2}$ Städtisches Klinikum, Frauenklinik, Karlsruhe

Key words
embryo
assisted reproductive
technology (ART)
ICSI
patient decision-making
Embryo Protection Law
Schlüsselwörter
Embryo
assistierte Reproduktion
ICSI
Patientinnenwunsch
Embryonenschutzgesetz

Deutschsprachige Zusatzinformationen online abrufbar unter: www.thieme-connect.de/ ejournals/toc/gebfra

\section{received 22.9.2013 \\ revised $\quad 12.12 .2013$ \\ accepted 31.12.2013}

\section{Bibliography}

DOI http://dx.doi.org/

10.1055/s-0033-1360344

Geburtsh Frauenheilk 2014; 74

157-160 @ Georg Thieme

Verlag KG Stuttgart · New York ISSN 0016-5751

\section{Correspondence}

PD Dr. Susanne Cupisti

University Hospital

Gynaecology and Obstetrics

Universitätsfrauenklinik

Erlangen

Universitätsstraße 21-23

91054 Erlangen

susanne.cupisti@

uk-erlangen.de

\section{Abstract \\ $\nabla$}

Background: The aim of this study was to evaluate how many embryos will develop if more than 3 2-pronuclei-stage oocytes (2-PNOs) are cultured at the patient's request and in accordance with the Germany Embryo Protection Law.

Methods: A total of 106 cycles of patients undergoing their $1 \mathrm{st}, 2$ nd or 3rd cycle of IVF or ICSI treatment in 2010 were prospectively included in the study. In each individual case, a decision was taken prior to treatment about the number of 2-PNOs to be cultured after each cycle.

Results: Ninety female patients were treated for a total of 106 cycles. A mean of two to six 2-PNOs were cultivated for a period of between 3 and 6 days for each patient. After culture, no viable embryo was identified for 5 patients (4.7\%), a single viable embryo was identified for 37 cycles (34.7\%), and 2 viable embryos were identified for 52 cycles (48.8\%). Eleven patients (10.3\%) had 3 viable embryos after a further 11 cycles and 1 patient had 4 viable embryos in a single cycle. Ten of the patients with 3 embryos each opted to have all 3 embryos transferred in the same cycle. This meant that a single embryo from one patient with 3 viable embryos and a single embryo of the patient with 4 viable embryos were cryopreserved after culture. The pregnancy rate was $19 \%$ per embryo transfer and 25\% per blastocyst transfer (20 pregnancies in total). All cryopreserved embryos were transferred in a subsequent cycle.

Discussion: Based on this study it is possible to make a statement about the number of viable embryos which should be cultivated to obtain, at best, two embryos for transfer without running an unacceptably high risk of producing too many embryos which would then need to be cryopreserved. Only 12 patients (13.3\%) had more than 2 viable embryos. The number of supernumerary pre-implantation-stage embryos was acceptably low (only 2 patients had additional viable em-

\section{Zusammenfassung \\ $\nabla$}

Hintergrund: Das Ziel der vorliegenden Untersuchung war, zu evaluieren, wie viele Embryonen sich entwickelten, wenn auf Wunsch der Patientinnen individuell mehr als 3 2-PN-Stadien von Oozyten (2-PNOs) kultiviert wurden, vor dem Hintergrund der Bestimmungen des Deutschen Embryonenschutzgesetzes.

Methoden: Es wurden 106 Zyklen von Patientinnen prospektiv eingeschlossen, die ihren 1., 2. oder 3. Zyklus einer IVF- oder ICSI-Behandlung 2010 durchführten. Mit jedem Paar war zuvor individuell festgelegt worden, wie viele 2-PNOs weiter kultiviert werden sollten.

Ergebnisse: 90 Patientinnen wurden in $106 \mathrm{Zy}$ klen individuell behandelt. Pro Patientenpaar wurden durchschnittlich 2 bis 6 2-PNOs für 3 bis 6 Tage kultiviert. Nach der Kultur waren keine vitalen, d.h. weiter in Kultur entwicklungsfähigen Embryonen mehr identifizierbar für 5 Patientinnen (4,7\%), ein einzelner vitaler Embryo war nachweisbar in 37 Zyklen (34,7\%), und 2 vitale Embryonen waren nachweisbar in 52 Zyklen $(48,8 \%)$. Elf Patientinnen in weiteren 11 Zyklen (10,3\%) hatten 3 vitale Embryonen und 1 Patientin hatte 4 Embryonen in einem einzelnen Zyklus. Zehn Patientinnen mit 3 Embryonen wurden auf Wunsch alle 3 Embryonen transferiert; d.h. ein einzelner Embryo einer Patientin sowie ein einzelner Embryo der Patientin mit 4 vitalen Embryonen mussten nach Kultur kryokonserviert werden. Die Schwangerschaftsrate lag bei 19\% pro Embryotransfer und 25\% pro Blastozystentransfer (insgesamt 20 Schwangerschaften). Alle kryokonservierten Embryonen wurden in einem nachfolgenden Zyklus transferiert.

Diskussion: Aufgrund dieser Untersuchung erscheint es möglich, eine Aussage über die Anzahl der vitalen Embryonen zu machen, die man kultivieren sollte, um im besten Falle 2 Embryonen zum Transfer zu erhalten, ohne das zu hohe Risi- 
bryos, $2.2 \%$ ). This means that it is possible to fulfil the wishes of individual patients while complying with the German Embryo Protection Law. ko, zu viele überzählige Embryonen zu produzieren, die dann kryokonserviert werden müssten. Mehr als 2 Embryonen entwickelten sich nur bei 12 Patientinnen (13,3\%). Die Rate an sozusagen überzähligen Embryonen im Präimplantationsstadium war akzeptabel gering (bei 2 Patientinnen, 2,2\%). Damit kann der jeweilige Patientinnenwunsch nach Individualisierung der Behandlung auch unter Einhaltung der Bestimmungen des Embryonenschutzgesetzes erfüllt werden.

\section{Introduction}

In Germany, reproductive medicine is hedged about by numerous legal regulations and the framework guidelines issued by professional associations. In particular, reproductive medicine in Germany must comply with the Embryo Protection Law of 1991. The aim of the Embryo Protection Law is to protect the health of the patient and her partner, to safeguard the options available to couples with today's assisted reproductive technology and to protect the life of the unborn child.

According to Art. 1, para 1, sentences 2 and 3 of the German Embryo Protection Law, it is not permitted to transfer more than 3 embryos from one woman in a single cycle; moreover, it is not even permitted to fertilise more oocytes of a woman than the number intended for transfer in a single cycle [1]. The latter prohibition, if it were taken literally, would represent a significant disadvantage for affected couples with respect to their chances of becoming pregnant. It is therefore common practice in Germany to fertilise all mature oocytes but only to culture a maximum of 3 embryos at once. This practice is not considered to be contrary to the legislative intent or the regulations of the professional associations.

The strict recommendations issued by the professional associations of fertility doctors formally comply with the legislative text; this means that two is usually the maximum number of embryos scheduled to be cultured and transferred, as the aim is to prevent increased rates of multiple pregnancies. For this reason, the maximum number of embryos transferred in a single cycle would ideally be 2 [2-4].

For fertility doctors in Germany, the question therefore arises, depending on the patient's individual situation, how many 2PNOs are required for culturing in order to reliably obtain 2 viable embryos for transfer [5].

The aim of this study was to investigate how many viable embryos will develop if more than 32 -PNOs are cultured and the wishes of the individual patient are taken into account.

\section{Patients and Methods}

$\nabla$

Ninety consecutive patients undergoing their 1st, 2nd or (in 7 cases) 3rd IVF with ICSI cycle in 2010 were prospectively investigated. Hormonal stimulation treatment consisted of the long protocol with a $\mathrm{GnRH}$ analogue for down-regulation as follows: triptorelin (Decapeptyl IVF) $0.1 \mathrm{mg}$ daily, administered subcutaneously (Ferring, Kiel, Germany) and either follitropin alfa 200 IU daily, administered subcutaneously (Gonal-f; Merck Serono, Darmstadt, Germany) or menotropin 225 IU daily, administered subcutaneously (Menogon HP, Ferring, Kiel, Germany). Once the dominant follicle had grown to a size of $20 \mathrm{~mm}$, ovulation was induced using chorionic gonadotropin, 10000 IU administered by injection (Brevactid, Ferring, Kiel, Germany). Transvag- inal follicle puncture for oocyte retrieval was done 36 hours later. This was followed by intracytoplasmic sperm injection. Evaluation of the number of 2-PNOs and selection of cells for further embryo culture was done the next day. The couples were informed of the result.

The situation was discussed with each couple and the situation of the respective patient considered (age of the patient, number of previous cycles, patient's wish regarding the number of embryos to be transferred). A decision was then taken about the number of 2-PNOs to be selected for further culture and the number of 2PNOs which would initially be cryopreserved to ensure that, after culturing for a maximum of 5 days, not more than 2 viable embryos would be available for transfer. The wishes of the couple were taken into account.

The standard conditions for transfer were defined as follows: maximum culture duration of 6 days; transfers carried out only on weekdays. The option of cryopreservation was offered to patients who had at least six 2-PNOs.

Progesterone, $3 \times 200$ mg daily (Utrogest; Dr. Kade Pharmazeutische Fabrik, Berlin, Germany) was administered intravaginally to support the luteal phase after embryo transfer. Fourteen days after embryo transfer, a pregnancy test was done by testing for hCG in serum.

\section{Statistical analysis}

Statistical analysis was done using the Statistical Package for the Social Sciences (SPSS, version 18.0 for Windows; SPSS, Inc., Chicago, Illinois, USA).

\section{Results \\ $\nabla$}

\section{Population}

A total of 90 patients were treated over 106 ICSI cycles using this individualised protocol. The couples had been trying to have a baby since 2 years (median). Primary sterility was present in 21 couples (23.3\%) and secondary sterility in 69 couples (76.7\%). Mean/median age of the woman was 33 years. There was a single cause of sterility in 65 cases (72.2\%), while there were several causes in 25 cases (27.8\%). Causes of sterility were: 14 cases with hormonal problems (15.56\%), 21 cases with tubal sterility (23.33\%), 12 cases with endometriosis (13.33\%), 51 cases with andrological causes of sterility (56.67\%) and 16 cases of unknown causation (17.78\%) ( Fig. 1). A mean of 10.7 oocytes was retrieved per patient (median: 9.5). A mean of 7.3 oocytes reached the 2-PNO stage (median: 6).

\section{Decision-making process}

After consultation with each couple and in accordance with our standard conditions stated above, the following decisions were jointly made: in cases where there was a maximum of 5 2-PNOs (45 couples) all cells were cultivated further. In cases with 6 
2-PNOs (10 couples), 3 couples opted to have 3 2-PNOs cultured, 4 couples chose to have 42 -PNOs cultured and 3 couples decided to have all 6 2-PNOs cultured further. The latter 3 couples included patients aged at least 38 years. In cases with 7 2-PNOs (17 couples), one couple chose to have 3 cells cultured, 15 couples requested that 4 cells be cultured and one couple decided to have 5 cells cultured: in the latter case, the patient was 38 years old and was already on her 2nd ICSI cycle. In the cases with 8 or more 2-PNOs ( 34 couples), decisions were taken by the individual couples to have 3, 4 or 5 2-PNOs cultured with cryopreservation of the remaining cells.

The medical recommendation was to culture 5 2-PNOs for all women aged more than 30 years, for all women in their 2 nd or 3rd ICSI cycle and for all women who did not have more than 5 2-PNOs at the outset.

\section{Results of culture}

A mean of 4.3 2-PNOs were cultured (median: 4). A mean of 1.6 viable embryos (median: 2 ) developed after a mean culture time of 4.4 days (median: 4 days).

A total of 178 viable embryos developed, i.e., embryos which developed regularly up until the planned time of transfer. 176 (96.8\%) embryos were transferred in the same cycle. In 37 cycles in 35 patients only 1 embryo developed and was transferred (34.7\%). In 52 cycles in 43 patients, 2 embryos developed and were transferred (48.8\%). In 11 cycles in 11 patients 3 embryos developed, and in 1 patient 4 embryos developed (10.3\%). In this patient, 3 embryos were transferred and the additional embryo was cryopreserved. In another patient with 3 viable embryos, 1 embryo was also cryopreserved, as the patient definitely only wanted to have 2 embryos transferred. Blastocysts were transferred in 8 cycles ( $7.5 \%$ ).

Only 5 patients ( 5 cycles) had no viable embryos (4.75\%), and no embryos were transferred in these women.

The implantation rate was $8.9 \%$. There were 20 pregnancies, i.e., $19.8 \%$ per embryo transfer and $18.87 \%$ per cycle ( $\mathbf{O}$ Fig. 2 ). No multiple pregnancies occurred. Only 2 viable embryos (1.1\%) of 2 patients ( 2 cycles, $1.8 \%$ ) were cryopreserved. All cryopreserved embryos were transferred in a later cycle. There was no "stockpiling" of embryos. The 20 pregnancies resulted in 4 miscarriages and 16 live births.

\section{Discussion}

$\nabla$

This study shows that it is possible to reliably obtain 2 or a maximum of 3 viable embryos for transfer, if patients are advised on an individual basis and the decision is taken together with the couple. Almost $97 \%$ of all viable embryos were transferred in the same cycle if up to 5 2-PNOs were previously cultured. The number of cycles with embryos which could not be transferred in the same cycle was very low $(4.7 \%)$.

The German Medical Association (Bundesärztekammer [BÄK]) has interpreted the requirements of the German Embryo Protection Law in such a way that their interpretation is known as the "three-point rule". In the guidelines issued in 1998 and 2006, the BÄK stated that this is their recommended method of treatment $[1,6,7]$. However, if this interpretation of the Embryo Protection Law is faithfully adhered to, then the fact is that it will not be possible to initially cultivate more than 2-PNOs. This would entail a lower success rate (i.e., lower pregnancy rates) just to ensure that multiple pregnancies are avoided at all costs. Moreover,

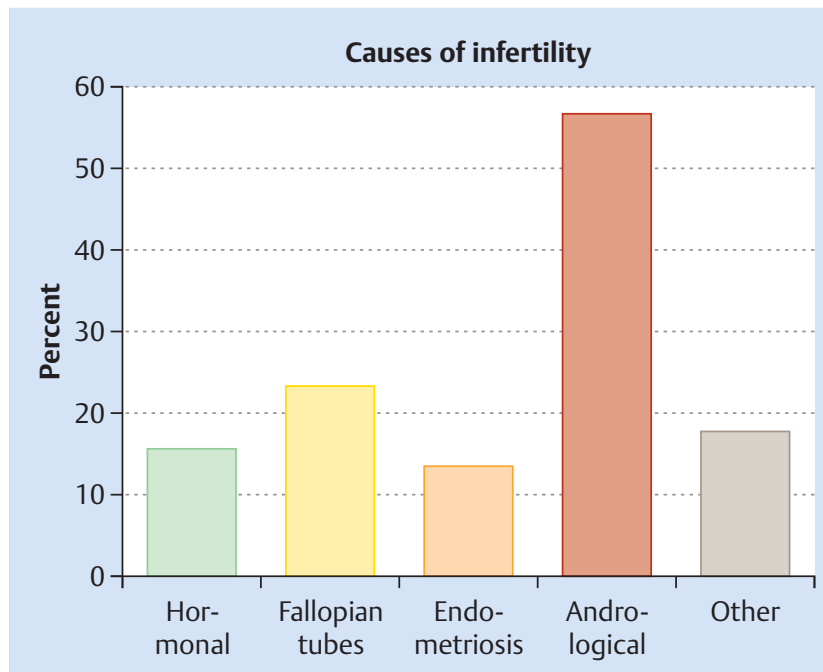

Fig. 1 Causes of infertility in 90 patients in percent (more than one causative factor possible per patient).

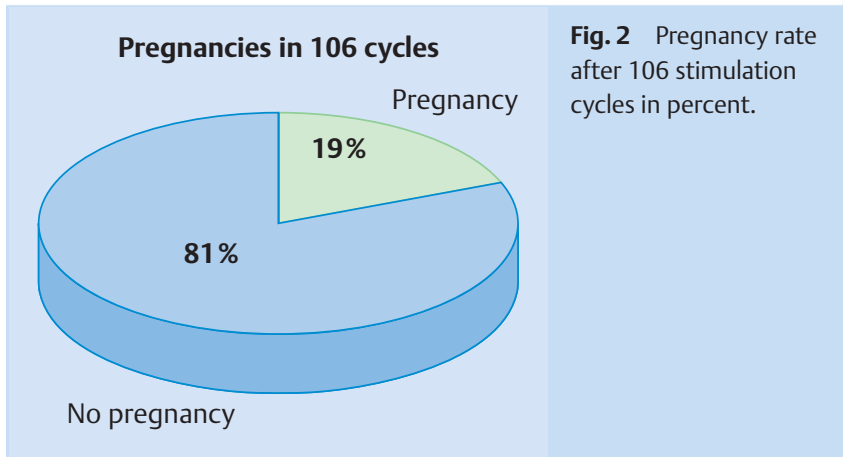

their interpretation does not take account of the individual circumstances of patients (e.g., patients with limited ovarian reserve and fewer oocytes per se at the start of culturing). Because of these considerations, this interpretation of the Embryo Protection Law needs to be scrutinised critically.

It is important to particularly consider the following aspects:

- Not all 2-PNOs go on to develop regularly; only a few will develop into viable embryos after cultivation.

- At the time the law was passed in 1990, it was not yet possible to forecast how many embryos could be cultured starting from the 2-PNO stage.

- Since then, a lot of progress has been made in culturing 2-PNOs until they reach the blastocyst stage, so that, in general, only a maximum of two embryos are transferred in a single transfer $[3,4]$.

- Given the easy accessibility of information via the internet and patients' increased self-confidence and wish for self-determination, today's physicians are increasingly finding the need to take account of the individual wishes of their patients and to actively include their patients in treatment decisions.

The relevant guidelines by the professional associations should therefore be reconsidered.

It is important to emphasise that it is not the Embryo Protection Law as such which places limitations on the culturing of embryos but the corresponding guidelines issued by the professional asso- 
ciations. The interpretation offered by the German Medical Association is only one potential interpretation of the Embryo Protection Law. Thus, the Embryo Protection Law does not forbid the cryopreservation of embryos. Quite the contrary: the law even states (in Art. 9 para 3) that "The conservation of a human embryo and of a human oocyte is permitted" [1]. In this point it appears that the Embryo Protection Law is much more liberal than many of the interpretations derived from it. This interpretation has already been debated in previous studies and was confirmed both scientifically and legally in subsequent years (2000) [9-11]. Even if one allows for the attempts by fertility doctors to avoid higher-order multiple pregnancies, the described procedure with the transfer of 2 embryos means that it is possible to offer couples a successful method which is compatible with the Embryo Protection Law [3-5, 12]. In Germany, the general medical consensus is that the number of embryos transferred in a single cycle should depend on the age of the mother. In our experience, we found that it was possible to create 2 good quality embryos (on average) which were suitable for transfer through culturing 5 2-PN stages while taking account of the individual situation and the wishes of the couple.

This study was done in a patient population undergoing IVF with ICSI. Fertility issues were average for such patient cohorts with regard to duration of sterility, maternal age and causes of sterility. More than 2 embryos were only created in $10 \%$ of cycles, and more than 3 embryos were only created in one cycle out of a total of 106 cycles. Most couples wanted all 3 embryos to be transferred because of maternal age, so that only in 2 cases did more embryos develop than were transferred in the same cycle. These supernumerary embryos were cryopreserved and all of them were transferred in a later cycle. Thus, no longer-term stockpiling of embryos occurred - something the Embryo Protection Law wishes to prevent [1]. On the contrary, no non-viable embryos (which would theoretically also be protected by the Embryo Protection Law) were cryopreserved [13]. These results were in accordance with what we had expected.

Given these facts, it is worth questioning whether the Embryo Protection Law is really as restrictive and disadvantageous to couples as is often thought, and whether a new law to deal with this issue is really necessary - particularly in view of the fact that any amendments to the law are currently extremely unrealistic. Both the "liberal" interpretation of the Embryo Protection Law presented in this study and the "formal" interpretation of the law by the German Medical Association are legally correct. However, an adjustment to the approach recommended by the professional associations appears more realistic and more necessary. The Embryo Protection Law forbids research to be conducted on embryos; this prohibition would be completely unaffected by the proposed adjustment, although some authors have pointed out that the current situation with regard to reproductive medicine has had a detrimental impact on scientific research in this field in Germany compared to other countries - and thus has also disadvantaged infertile couples in Germany [14].

In short, it must be stated that neither the Embryo Protection Law nor the recommendations issued by professional associations should be interpreted restrictively, i.e. such that they limit the chances and wishes of affected couples. It is entirely feasible to include couples in decisions on treatment while complying with medically recommended options and legal regulations.

\section{Practical relevance}

Culturing more than 32 -PN stages is compatible with the German Embryo Protection Law. It is possible to estimate how many 2-PN stages are capable of developing further to ensure that at least 2 , and in exception cases 3 , good quality embryos are available for transfer. Given these conditions, the rates of embryos which cannot be transferred in the same cycle and therefore need to be cryopreserved will be acceptably low. This framework would make it possible to take account of the wishes of individual patients.

\section{Conflict of Interest}

$\nabla$

The authors state that they have no conflict of interest.

\section{References}

1 Gesetz zum Schutz von Embryonen (Embryonenschutzgesetz - ESchG) (1990) 13 December 1990 (Bundesgesetzblatt I 1990, p.2746), current version 23.10.2001 (Bundesgesetzblatt I 2001, p. 2702)

2 Günther HL, Taupitz J, Kaiser P. Embryonenschutzgesetz: Juristischer Kommentar mit medizinisch-naturwissenschaftlichen Einführungen. 2. Aufl. Stuttgart: Kohlhammer; 2008

3 Geisthövel F. Plenarvortrag „DVR - eine Standortbestimmung“. 1st DVR-Kongress. Münster i.W., 08.-20.12.2005. J Reproduktionsmed Endokrinol 2006; 3: 65-73

4 Frommel M. Deutscher Mittelweg in der Anwendung des Embryonenschutzgesetzes (ESchG) mit einer an den aktuellen wissenschaftlichen Kenntnisstand orientierten Auslegung der für die Reproduktionsmedizin zentralen Vorschrift des $\S 1$, Abs. 1, Nr. 5 ESchG. J Reproduktionsmed Endokrinol 2007; 4: 27-33

5 Geisthövel F, Frommel M, Ludwig M. Aufklärung und Vereinbarungen für die In-vitro-Fertilisations-Therapie und die Kryokonservierung von Embryonen - ein Diskussionsbeitrag. J Reproduktionsmed Endokrinol 2004; 1: 289-294

6 Bundesärztekammer. Richtlinien der Bundesärztekammer zur Durchführung der assistierten Reproduktion. Deutsches Ärzteblatt 1998; 95: A-3166-A-3171

7 Bundesärztekammer. (Muster-)Richtlinie zur Durchführung der assistierten Reproduktion - Novelle 2006. Dtsch Ärztebl 2006; 103: 13921403

8 Frommel M. Auslegungsspielräume des Embryonenschutzgesetzes. J Reproduktionsmed Endokrinol 2004; 1: 104-111

9 [Specialist medical societies]. Positionspapier zu den Vorbereitungen für ein Fortpflanzungs-Medizingesetz (FMG) als Ergebnis einer Konsensustagung der Deutschen Gesellschaft für Gynäkologische Endokrinologie und Fortpflanzungsmedizin (DGGEF) e.V., der Deutschen Gesellschaft für Gynäkologie und Geburtshilfe (DGGG), der Deutschen Gesellschaft für Reproduktionsmedizin (DGRM) und des Bundesverbandes Reproduktionsmedizinischer Zentren (BRZ), Freiburg im Breisgau, 6 October 2000. Online: http://www.repromedizin.de/fileadmin/ presse/positionspapierfortpflanzungsmedizingesetz_2000.pdf

10 Coester-Waltjen D. Reformüberlegungen unter besonderer Berücksichtigung familienrechtlicher und personenstandsrechtlicher Fragen. Das Recht der Fortpflanzungsmedizin im 21. Jahrhundert. Reproduktionsmedizin 2002; 18: 183-198

11 [Court judgment]. Amtsgericht Wolfratshausen vom 30.04.2008. Az 6 C 677/06

12 Berufsverband Reproduktionsmedizin Bayern. Das Deutsche Embryonenschutzgesetz ist besser als sein Ruf. Stellungnahme des Berufsverbands Reproduktionsmedizin Bayern e.V., München, 29.06.2007. Online: http://www.br-bayern.de/Presseinfo-2.pdf

13 Bals-Pratsch M, Dittrich R, Frommel M. Wandel in der Implementation des Deutschen Embryonenschutzgesetzes. J Reproduktionsmed Endokrinol 2010; 7: 87-95

14 Diedrich $K$, Strowitzki T, Kentenich $H$. The state of reproductive medicine in Germany. Geburtsh Frauenheilk 2012; 72: 225-234 